Article

\title{
Are Corporate Environmental Responsibility Activities an Efficient Investment or an Agency Cost? Evidence from Korea
}

\author{
Sang Koo Kang ${ }^{1}$ and Hee Sub Byun ${ }^{2, *}$ \\ 1 Department of Business Administration, Kyonggi University, 154-42, Gwanggyosan-ro, Yeongtong-gu, \\ Suwon-si, Gyeonggi-do 16227, Korea; kang409@kgu.ac.kr \\ 2 Department of Finance, College of Business, Hallym University, 1 Hallymdaehak-gil, Chuncheon, \\ Gangwon-do 24252, Korea \\ * Correspondence: heesbyun@hallym.ac.kr
}

Received: 10 April 2020; Accepted: 3 May 2020; Published: 5 May 2020

\begin{abstract}
External conditions such as capital market maturity, investor protection levels, and government control over individual firms vary among countries. We posit that such environmental differences could cause differences in corporate environmental responsibility (CER) activities between countries. However, previous studies have mainly focused on developed countries, while studies conducted in emerging countries are limited. We examine the relationship between CER activities and investment inefficiency in firms listed on the Korea Exchange. Specifically, we analyze the incentive of managers' ex-ante behavior on CERs and further analyze the relationship between these incentives and external evaluations. Using firm-year panel data, we conducted the pooled ordinary least squares (OLS) regression analysis and found the following results. First, the relationship between CERs and investment inefficiency is significantly positive, especially those based on managers' incentives for overinvestments. Second, the positive relationship between CERs and investment inefficiency is prominent in the subsamples with large free cash flows or low asset efficiency. Third, active CERs reduced corporate value in the overinvestment subsample. Unlike existing literature that focuses on developed countries, our results imply that CERs may have negative effects due to agency problems in emerging countries with immature capital markets. From this arises the academic implication that the evaluation of CERs should be changed according to different capital market environments.
\end{abstract}

Keywords: corporate environmental responsibility; investment inefficiency; agency cost; overinvestment; emerging market

\section{Introduction}

Previous studies argue that corporate environmental responsibility (CER) activities are efficient investment alternatives that can contribute to the maximization of corporate value by expanding corporate sustainability [1-3]. Other studies counter this perspective and espouse that, owing to agency problems, CER activities may be abused by managers in pursuit of private benefits. Managers can arbitrarily influence CER activities depending on their ownership [4,5]. They can be problematic because they often distort corporate investment decisions toward increasing their private benefit by abusing their right of control. Agency problems are more serious in emerging countries than in developed countries due to high information asymmetry and low transparency. External conditions such as capital market maturity, investor protection levels, and government control over individual firms vary among countries. We posit that such environmental differences could cause differences in CER activities between countries. Previous studies have mainly focused on developed countries, while studies conducted in emerging countries are limited. 
Critics of CER activities maintain that CER activities are commonly inefficient investments based on agency problems, even though incentives could be different. Managers have an incentive to overinvest to form a good reputation and to increase their discretionary power over corporate resources [6]. CER activities can be exploited as a tool to build managers' reputations and signal their ethicality [4]. At the same time, managers have an incentive to underinvest. Incompetent managers who fail to secure investment opportunities in business may expand into unnecessary CER activities to conceal their incompetence. Again, CER activities can be exploited to mask managers' neglect and cover risk-averse dispositions [7]. On the contrary, studies on the positive functions of CER activities argue that CER activities generate benefits such as reduced production costs, increased labor productivity, and improved risk management [8-10]. These conflicting arguments raise empirical questions about whether CER activities are inefficient or profitable investments made by managers. If CER activities are a good means of investment involving positive functions, they are expected to lower the levels of over- and under-investments.

The relationship between CER activities and the investment inefficiency of Korean companies is empirically analyzed in this study. Specifically, the incentives of managers' ex-ante behavior on CERs are analyzed, and further, the relationship between these incentives and external evaluations is analyzed. Since CER activities involve high costs, they should be carried out in consideration of the diverse characteristics of the company, such as growth opportunities and financial capacity. If the costs of CER activities are larger than the benefits of CER activities, CER activities may have negative effects on the company. Therefore, it is necessary to empirically verify whether a company's CER activities are at an appropriate level. Existing studies judge the adequacy of CER activities based on external assessments formed in the capital market, such as corporate value and costs of capital [11-13]. Meanwhile, studies on the internal investment policies of companies are limited [14,15]. Given the high level of information asymmetry and the incompleteness of capital markets in emerging countries, external assessments can be distorted by the unobservable characteristics of companies, environmental factors, and the possibility of managers concealing information. Therefore, when we judge the adequacy of CER activities in emerging countries, ex-ante management behavior reflecting managerial incentives could be more effective than ex-post assessments in the capital market.

Analyzing CER activities in Korea has two main advantages. First, given the characteristics of the capital market, and the rapid growth of CER activities in Korea, the CER activities of Korean companies are at high risk of being abused due to agency problems. Previous studies have shown high levels of information asymmetry, low levels of investor protection, and owner-managers' pursuit of private benefit in Korea despite the fact that Korea is an advanced emerging country [16,17]. In addition, unlike the United States, where the base of CER activities has been accumulated over a long period of time, Korean interest in CER activities has expanded rapidly in a short period of time. Unlike China, where the level of government control over CER activities is high due to the predominance of state-owned enterprises, CER activities in Korea are carried out autonomously by private enterprises. Second, qualitative data on CER activities in Korea are available. This study utilizes the results of the firm-level evaluation of environmental management by the Korea Corporate Governance Service (KCGS) as a proxy for CER activities. KCGs's data on CER activities are subdivided into five categories: Strategy, organization, management, performance, and responses to stakeholders, to facilitate quantitative and qualitative analyses. In addition, concrete pathways can be studied using the five categories of CER activities. The foregoing is expected to complement existing studies.

The major findings of this study are as follows. First, active CER activities lead to investment inefficiency, especially based on managers' incentives for overinvestments. This result was consistent and robust even when the endogeneity problem based on the reverse causality between CER activities and investment inefficiency was controlled using two-stage least square (2SLS). This means that in Korea, which is an advanced emerging country, CER activities are regarded as a means to privately benefit managers so that CER activities can be perceived as inefficient investments. This suggests that, unlike in developed countries, CER activities can be recognized as agency costs in emerging countries. 
Indeed, CER activities in Korea have been mainly concentrated on areas that can easily be expanded by managers in short periods of time, such as environmental strategies, environmental organizations, and environmental management.

Second, the positive relationship between CER activities and investment inefficiency is prominent in the subsamples with large free cash flows or low asset efficiency. That is, the relevant results appear prominently in the subsamples with high agency costs. This implies that the first result is not a phenomenon due to temporary increases in abnormal investment spending on CER activities but is based on managers' incentives to pursue private benefits. Third, active CER activities reduced corporate value in the overinvestment subsamples. For this, the entire samples are divided into overinvestment and underinvestment subsamples and the effects of CER activities on corporate value are verified. Many previous studies have verified the relationship between CER activities and corporate value. These studies evaluate the adequacy of CER activities through external assessments in the capital market. In contrast, the first result of this study shows that managers internally recognize CER activities as overinvestments. Therefore, overall, the results suggest that those CER activities that are internally evaluated by managers as overinvestments are also negatively evaluated in the external capital market.

This study contributes to the literature on the role of CER in at least three aspects. First, this study evaluated managers' incentives for CER activities using qualitative and quantitative data. Second, this study presents additional empirical grounds for conflicting studies on the functions of CER activity. In particular, this study showed that unlike developed countries, CER activities in emerging countries may have negative effects due to agency problems. Third, this study showed that managers' internal evaluations of CER activities could lead to consistent evaluations in external capital markets. Policy interest in CER activities has expanded recently in emerging countries. This study suggests that since CER activities can cause negative functions, policymakers should devise sophisticated systems that reflect diverse factors so that efficient CER investments can be made.

The remainder of this paper is organized as follows. Section 2 reviews the existing literature and develops our hypotheses. Section 3 describes the sample, variables, and empirical methodology. Section 4 reports the empirical results, while Section 5 concludes.

\section{Previous Literature and Hypotheses Development}

\subsection{Previous Literature}

Older studies considered CER activities as a sub-concept of corporate social responsibility (CSR) activities [18]. Contrarily, recent studies argue that CER activities should be analyzed individually. In fact, the risk of potential regulations over CER activities is high because related cost expenditures and legal binding power are larger compared to CSR activities. In emerging countries, environmental issues, such as air pollution and waste disposal, were not the first-order problems in the past. However, environmental issues are becoming more important and the relevance of CER activities is thus emphasized for both practitioners and policymakers. In some previous studies, there were limitations to the analysis owing to limited access to information on CER activities. Although CER activities can be assessed quantitatively using figures for energy consumption, water consumption, and carbon emissions, they can also be qualitatively assessed using managerial intent, policy-making, and the spread of education. Comprehensive information on CER activities is therefore necessary, especially to determine which areas of CER activity are potentially efficient investments [19]. In this respect, data from KCGS used in this study proved advantageous.

Stakeholder theory argues that CER activities generate sufficient benefits to cover the costs involved. This theory argues that CER activities must satisfy the interests of diverse stakeholders, including shareholders, communities, suppliers, and consumers, and can thereby expand the sustainability of management activities. Therefore, the greater the involvement in CER activities, the more the improvement in companies' value and management performance. Blacconiere and Patten [11] showed 
that when a chemical leak accident occurred, the decline in stock prices of companies engaged in CER activities was lower than for other companies within the same industry. Klassen and McLaughlin [1] showed that when the excellence of a company's CER activities was recognized through awards from external agencies, the price-earnings ratio of the stocks of the company significantly increased. Welch, Ashish, and Yasuhumi [2] showed that the management performance of companies in which CER activities were internationally certified was higher than that of companies whose CER activities were not certified.

On the contrary, a series of studies negatively evaluated CER activities due to agency problems. Friedman [20] argues that CSR or CER activity undertaken to satisfy stakeholders' interests do not conform to the interests of shareholders and, therefore, can be viewed as expenditures due to the agency problems of managers. CER activities can be exploited as a means of building managers' reputations; this argument implies that CER activities are closely related to agency problems [4]. Indeed, some empirical research shows that active CER activities can reduce management performance [21]. In particular, if resources are allocated to unnecessary CER activities in a situation where growth opportunities and financing capacity are limited, investment opportunities may not be realized, leading to a reduction in profitability and growth potential in the company's own business area, eventually resulting in weakened competitiveness [22,23]. Gangi and Varrone [24] show that the portfolios of European socially responsible funds paradoxically exhibit poorer corporate social performance than the portfolios of European conventional funds and raise concerns about the validity of screening by socially responsible funds.

Even when agency problems exist, managers' perceptions of CERs may vary with their incentives. Barnea and Rubin [4] empirically showed a negative relationship between managers' shares and environmental, social, governance (ESG) elements. This shows that ESG activities are associated with agency problems, indicating that managers arbitrarily change ESG activities according to their monetary incentives. Oh, Chang, and Martynov [5] showed a negative relationship between managers' shares and CSR in Korean companies. Lee, Byun, and Park [25] showed that ESG elements were expanded mainly in non-competitive commodity markets in Korea, unlike in developed countries. This indicates that the ESG elements are not used as a strategy to secure the competitive advantage of the company, but rather they are highly likely to be exploited for agency problems.

This study is not the first to verify the relationship between ESG elements and investment efficiency. Benlemlih and Bitar [18] argued that active CSR activities reduced investment inefficiency in the United States. Cheng, Ioannou, and Serafeim [14] found that active CSR activities reduced financial constraints in the United States. This means that active CSR activities in developed countries are useful for maintaining corporate sustainability by increasing companies' financial capacity. Zeng, Qin, and Zeng [15] showed a positive relationship between CER activities and investment efficiency in China. They also argued that such a relationship was possible only when efficient market environments already existed. This study is identical to that of Zeng, Qin, and Zeng [15], in that it was also conducted in an emerging country. However, unlike China, where government control over enterprises is strong, in Korea, CER activities are basically determined by managers. Due to differences in economic systems between China and Korea, this study is suitable for verifying the effects of CER according to managers' incentives. In addition, this study is expected to provide useful implications for capitalist countries. On the contrary, the above-mentioned studies mainly regarded CER activities as a sub-item of CSR activities and did not identify the path along which the effects of CER activities occur. The difference between this study and previous studies is that this study provides an analysis of that path.

Kliestik, Kovacova, Podhorska, and Kliestikova [26] examine the sources of goodwill creation in the Slovak Republic. They find that return on equity, net income, retained earnings, marketing costs, and investments to the plant are key sources of enterprise goodwill creation. Kliestik, Misankova, Valaskova, and Svabova [27] suggest a bankruptcy prediction model based on the financial information, e.g., liquidity, cash-holdings, capital structure, profitability, asset turnover, financing capacity. These researches are in line with this paper in that assessment of companies is based on financial information. 


\subsection{Hypotheses Development}

\subsubsection{Agency Problem and Corporate Environmental Responsibility (CER) Activities}

In agency theory, managers' arbitrary investment decisions are perceived as typical behaviors to pursue private benefits. Managers' private benefits are generally proportional to the size of the company. The increase in size is not only effective in flaunting managers' reputations but also increases the magnitude of managerial discretionary power. Therefore, managers can cause overinvestment problems $[6,28,29]$. In addition, the principal-agent problem can lead to underinvestments through entrenchment [30]. The essence of a firm is in taking risks. Contrarily, managers have an incentive not to adopt profitable investment projects to avoid temporary deterioration in accounting profits due to investment spending. In addition, managers may be conservative in adopting long-term investments that cannot be recognized as performance in their tenure [6].

CER activities can be recognized as agency costs, in that managers determine the level of CER activities. The grounds for the foregoing are as follows: First, CER activities are an easy way to build a good reputation for managers. Burkart, Panunzi, and Shleifer [31] argue that the private benefits of managers are proportional to non-pecuniary benefits such as reputation and amenity. Since CER activities are useful for managers to signal their ethicality to the market, managers are likely to opportunistically exploit CER activities. Indeed, interest in CER activity is increasing in global capital markets. Pension funds and asset management companies explicitly reflect the level of CER activity of individual companies, such as the introduction of ESG funds and the establishment of responsible investment policies for determining the composition of their investment portfolios. In addition, since the inducement of CER activities and regulations on environmental risks are introduced as policies, CER activities are important to many economic actors. Second, the adequacy of CER activities cannot be easily assessed in short periods of time [4]. The performance of CER activities cannot be accurately determined by external investors because of limited information. Furthermore, the current interest in CER activities in the capital market provides an environment where managers can easily avoid responsibility in the short term, even if their imprudent CER spending is the cause of the investment failure. Eventually, managers are more likely to abuse CER activities to pursue private benefits than to conduct rigorous assessments. Third, CER activities are highly likely to be exploited for political pressure [32]. Although CER activities are perceived as a means to satisfy stakeholders' needs, since they involve investment spending, they should be determined at the level where the benefits exceed costs. If CER activities are nevertheless utilized as a means to avoid pressure from stakeholders such as civic groups and communities or to respond to political pressure, the company may simply bear excessive costs. Therefore, if CER activities come from managers' agency problems, companies that are active in CER activities are highly likely to make inefficient investments.

Hypothesis 1. Active CER activities increase the company's investment inefficiency.

\subsubsection{CER Activities as an Efficiency Investment Alternative}

The benefits of CER activities can be realized through a variety of paths. New production processes and technologies introduced by companies for environmental conservation increase production efficiency [8]. Active CER activities contribute to the reinforcement of product competitiveness because there is consumer demand for companies that are active in environmental conservation [9]. In the same context, companies belonging to industries where product differentiation is difficult can effectively signal intrinsic values through CER activities [10]. Additionally, the adoption of environmental standards by companies enhances labor productivity by contributing to greater social identification of employees and efficient work systems [33].

CER activities reduce information asymmetry and can be used as a risk management tool. Cui, Jo, and $\mathrm{Na}$ [34] argue that information asymmetry is reduced in the process of implementation of ESG 
activities because accessibility to internal information is improved during that process. For instance, the introduction of sustainability reports is a representative example. In addition, the expansion of investment strategies considering ESG elements can induce the supply and dissemination of information by analysts and institutional investors. A reduction in information asymmetry reduces the cost of capital and will, therefore, contribute to the elimination of financial constraints. Gangi, Meles, Monferrà, and Mustilli [35] show that both CSR engagement and corporate governance mechanisms have a significantly negative influence on the firms' risk of financial distress. Therefore, CER activities can be useful in easing the constraints in raising external capital and realizing companies' growth opportunities on time.

CER activities can be regarded as an insurance-like alternative to proactively prevent the possibility of litigation and regulatory risks for environmental accidents [36]. Environmental accidents can lead to monetary and non-monetary losses for companies, due to direct economic losses and the possibility of litigation. In addition, the introduction of regulations on environments can act as a factor that limits business activities. Cai, Cui, and Jo [3] argue that active CER activities significantly reduce corporate risks.

The above arguments suggest that CER activities can serve as an efficient investment alternative with diverse and beneficial functions. At the same time, CER activities reduce information asymmetry to increase information supply, while also being useful for risk management. Therefore, CER activities would be useful for improving the investment efficiency of companies.

Hypothesis 2. Active CER activities decrease the investment inefficiency of the company.

\section{Samples, Variables, and Methodology}

\subsection{Sample}

This study analyzes companies listed on the Korea Composite Stock Price Index (KOSPI) market of the Korea Exchange (KRX) as initial samples and the sample period is from 2011 to 2015. Financial and insurance companies were excluded because of the low comparability of financial statements. Firms of which the capitals were impaired were also excluded. Samples of which independent variables or control variables could not be calculated were excluded. Finally, 2471 firm-year observations consisting of 663 unique firms were analyzed as samples. The results of the firm-level evaluation of environmental management by KCGS are used as proxies for CER activities. This assessment was carried out for all companies listed on the KRX since 2011. The financial and accounting information of the companies and stock price information were extracted from the Fn-Guide database.

\subsection{Variables}

\subsubsection{CER Activity Index}

This study utilizes the results of KCGs's firm-level environmental management evaluation as proxies for CER activities. The evaluation is carried out annually covering qualitative and quantitative information with a full score of 300 points. Since the evaluation of environmental management by the company is carried out with items set in advance by an external evaluation agency, there is little room for intervention by the researcher's arbitrariness. In addition, sampling bias is small because the samples include all listed companies in the KRX. Since the samples include a wide range of CER activity behaviors, the evaluation is less likely to present limited results concentrated on certain information. This study uses both the results of the overall evaluation and the results of evaluation by item and standardizes each score to a full score of 1 point to utilize the results for analysis. For example, the variable CER is a value obtained by standardizing the score of the overall evaluation of which the full score is 300 points, based on a full score of 1 point. 
The firm-level evaluation of environmental management uses largely five items to evaluate the levels of CER activities. For the contents related to the evaluation items, the announced data on KCGS's website were referred to. Minimal explanations are also provided in Table A1 of the Appendix A. The full score of 300 points consists of 45 points for environmental strategy, 30 points for environmental organization, 115 points for environmental management, 85 points for environmental performance, and 25 points for responses to stakeholders. Environmental strategies (CER1) are judged based on the policies to implement CER activities and the establishment of related investment plans, and managers' will to practice is reflected. Environmental organizations (CER2) are evaluated through whether there is an organization dedicated to the planning and execution of CER activities, whether periodic education is implemented, and a review of environmental management activities within the board of directors. Environmental management (CER3) is evaluated based on information on facility investments related to CER activities, management of chemicals and greenhouse gas emissions, review of and support for suppliers' environmental management, adoption of green procurement policies, and the establishment of an evaluation system for environmental performance. Environmental performance (CER4) is assessed with indicators that quantitatively assess CER activities, including greenhouse gas, waste, and chemical reductions, and water and energy savings. Responses to stakeholders (CER5) are evaluated based on information on disclosure and verification of environmental information, possession of communication channels with stakeholders, and support for and cooperation with the community for environmental preservation activities. The sub-item scores are also standardized to 1 point each when they are utilized.

The firm-level evaluation of environmental management by KCGS is not public and the data is thus unique. For this reason, this paper could not include the most recent CER index and it is a limitation of this research. Nevertheless, there has been no significant external shock during the periods from 2016 to 2019 that can make structural changes to firms' investment inefficiencies and/or CER activities. We thus believe that the results in this paper could represent the general behavior of managers and capital markets. However, further research is recommended to verify the results on the condition that more data becomes available.

\subsubsection{Investment Inefficiency}

Firms' investment inefficiency is assessed with the degree to which the investments of firms deviate from the optimum level derived considering internal characteristics such as growth opportunities, financing capacity, and capital structures. In this study, investment inefficiency is measured using the model proposed by Richardson [37]. This model is considered a more rigorous methodology in that more diverse variables are controlled compared to other models and there is no limit to the number of firms in the industry. This model recognizes investment expenditures that cannot be explained with characteristics related to investment decisions such as growth opportunities, capital structures, and cash holdings as inefficient investments. Investment inefficiency is estimated according to Equation (1) below.

$$
\begin{aligned}
\text { Investment }_{i t+1} & =\beta_{0}+\beta_{1}{ }^{*} V / P_{i t}+\beta_{2}{ }^{*} \text { Leverage }_{i t}+\beta_{3}{ }^{*} \text { Cash }_{i t}+\beta_{4}{ }^{*} \text { Age }_{i t}+\beta_{5}{ }^{*} \text { Total asset }_{i t} \\
& +\beta_{6}{ }^{*} \text { Stock return }_{i t}+\beta_{7} \text { Investment }_{i t}+\eta_{t}+\lambda_{j}+\varepsilon_{i t}
\end{aligned}
$$

where, $i, t$, and $j$ refer to the firm, year, and industry, respectively. Investment is the value obtained by dividing the sum of capital expenditures and research and development (R\&D) expenses by total assets. $V / P$ proxies for growth opportunities and is calculated by dividing firm value $(V)$ by the market value of equity $(P)$. Firms with many growth opportunities will naturally increase their investment spending. $V=(1-\alpha r) B V+\alpha(1+r) X-\alpha r d$ is estimated and $\alpha=(\omega /(1+r-\omega))$ is defined. $r=0.12$, $\omega=0.62$. $B V$ refers to the book value of common stocks, $d$ refers to the amount of dividends, and $X$ refers to operating profits before depreciation. The variable Leverage is the ratio of total liabilities to the total assets. High liabilities are accompanied by interest costs and bankruptcy risk. Therefore, this burden is expected to reduce investment expenditure. The variable Cash is the ratio of cash and 
cash equivalents to the total asset. The amount of cash represents the internal funding capacity for investments. Therefore, firms with large amounts of cash can expand their investment spending sufficiently. Age is obtained by taking the natural logarithm of the firm's history in years. The firm's age refers to the business cycle. Firms need high investment spending in the early stages of growth. Total asset is obtained by taking the natural logarithm of the total asset. The size of the firm's asset represents the scale and scope of the business, and its expansion is expected to increase investment expenditures naturally. Stock return is the annual stock return. This is a proxy for the managerial performance or capability evaluated in the stock market. High stock returns can increase investment expenditures by expanding the ease of external financing. Considering the average level of investment spending by firms, the lagged investment expenditure is included in the model. $\eta_{t}$ and $\lambda_{j}$ refer to the year dummy and industrial dummy variables, respectively. These variables reflect differences in the trend of investment spending by industry and year.

This study estimated the above equation using analytical samples and recognized the absolute value (Inefficiency1) or residual (Inefficiency2) of the residuals calculated from the equation as a proxy for investment inefficiency. The absolute value of the residuals refers to the degree of deviation from the optimal investment level and is a setting that does not distinguish between overinvestment and underinvestment. On the other hand, larger values of residual mean increase in the level of overinvestments, while smaller values of residual mean increase the level of underinvestments and include the meaning of directivity. The result of estimation using the samples in this study is as shown in Equation (2) below.

$$
\begin{aligned}
& \text { Investment }_{i t+1}=-0.0056-0.0035{ }^{*} V / P_{i t}-0.0028{ }^{*} \text { Leverage }_{i t}+0.0421{ }^{*} \text { Cash }_{i t}-0.0007{ }^{*} \text { Age }_{i t} \\
& +0.0015{ }^{*} \text { Total asset }_{i t}+0.0024{ }^{*} \text { Stock return } \\
& \text { it }
\end{aligned}
$$

The paths of investment inefficiency are divided into overinvestments and underinvestments based on agency theory. To this end, a variable that takes the absolute value when the residual in Equation (1) above has a value greater than zero and has the value of 0 when the residual has a value smaller than 0 is utilized as a proxy for the overinvestment level (Overinvest). In addition, a variable that takes the absolute value when the residual in Equation (1) above has a value smaller than zero and has the value of 0 when the residual has a value greater than 0 is utilized as a proxy for the underinvestment level (Underinvest). It is expected that through the variables divided as such, the clear directivity of CER activities can be identified whether they can improve or reduce investment efficiency through a path. Meanwhile, firms' investments can be divided into capital expenditures and R\&D expenses. Naturally, it should be possible to assess which investment expenditures will increase or reduce inefficiency and will be related to CER activities. To this end, investment expenditures are divided into capital expenditures and R\&D expenses, and the absolute values of the residuals of the results of the estimation of Equation (1) above using each of the foregoing as a dependent variable are utilized as additional indicators (Inefficiency $y_{C A P E X}$ and Inefficiency ${ }_{R E D}$ ).

\subsubsection{Control Variables}

A variety of control variables are included in the model in order to reduce the bias of omitted variables. First, size is added in order to control the effects of the scope of business according to the size of firms, the capacity available for investment expenditures, and growth stages. The variable Size is obtained by taking the natural logarithm of total assets. Increases in debts reduce the ability to invest due to the rise of interest costs and the risk of bankruptcy. On the other hand, these effects sometimes act as a regulatory function to reduce managers' arbitrary investment decisions in advance. Therefore, the variable Leverage is controlled and is the ratio of the total debt to equity capital. The firm's market value has a considerable influence on investment spending because it reflects future growth opportunities assessed in the capital market. This study thus controls the market-to-book ratio $(M T B)$ to the model. Firms' profitability can be considered as a major source of investment capital because it expands retained earnings. Therefore, to control this effect, the ratio of operating 
profits to the total asset $(E B I T)$ is added to the model. Dividends can reduce the capacity available for investment spending due to the outflow of the cash in possession. High dividends also have a bonding mechanism to guarantees the managers' fidelity and management ability. This study considers the ratio of the amounts of dividends to the total asset as a control variable (Dividend). The expansion of liquid assets means internal financing capacity that can be controlled by managers in short periods of time, and therefore can contribute to the expansion of arbitrary investment decisions. To control this effect, the ratio of liquid assets to the total asset is added to the model (Liquidity). Firms that are in a growing trend want to maintain the current trend through active investment expenditures. On the other hand, there is also the possibility for firms with a low growth potential to actively expand investment expenditures in search of growth opportunities. For this reason, the average of sales growth rates over the last five years is included as a control variable (Growth). Firm's management risks have an influence on investment expenditures because they are related to the stability of internal financing capacity and external financing costs. On the other hand, management risks also represent managers' stable management ability. This study measures management risks with the standard deviation of monthly stock returns over the last five years (Volatility).

This study uses a two-stage least square (2SLS) method to control for the possible endogeneity problem due to the reverse causality between CER activities and investment inefficiency. To this end, the industrial average CER activity index and the manufacturing industry dummy variable are used as instrumental variables. The former (Industry CER) is calculated as the average value of the CER activity index based on the three digits of the Korean standard industry code (KSIC). The latter (Manufacturing) is set by assigning a value of 1 to firms that fall under the manufacturing industry and 0 to other firms. Firms decide to conduct CER activities in order to gain a competitive advantage in the industry. Under this logic, the average level of CER activities in the industry has an influence on the level of execution of the activities of each firm [3]. CER activities may be affected by environmental risk levels, such as the exposure of the firm to chemicals and energy consumption. In this respect, unlike other industries such as the service industry, manufacturing firms that have large burdens of environmental risks in the process of production are expected to have the incentive to actively carry out CER activities. The adequacy of these instrumental variables will be discussed in detail together with the relevant empirical results.

To rigorously verify the relationship between CER activities and investment inefficiency according to managers' incentive to pursue private benefits, which will be addressed in the latter half of this paper, a proxy of agency problems is used. This study considers the amount of free cash flows and the turnover in comparison with the total asset, which is commonly mentioned in the agency theory. First, since an increase in free cash flow of a firm substitutes the amount of resources available for managers to divert, it means an increase in the possibility for managers to pursue private benefits. Free cash flow is calculated by dividing operating profits less interest costs, corporate tax, and dividend amount by the total asset (Free cash flow). Managerial ability is an indicator of asset efficiency (Managerial ability). Managers who do not use their assets efficiently can be inferred as showing incompetent behaviors of pursuing their own private benefits rather than management activities.

Tobin's $Q$ is used as a proxy for corporate value. Tobin's $Q$ is measured by dividing the sum of the market value of equity and the book value of liabilities by the book value of the total asset (Tobin's $Q$ ). In analyzing the determinants of corporate value, in addition to the variables defined earlier, Market-cap obtained by taking the natural logarithm of market capitalization and Cash, the ratio of cash and cash equivalent to the total asset, are controlled.

\subsection{Methodology}

This study utilizes the ordinary least squares (OLS) regression analysis as the main analysis methodology. The samples of this paper are firm-year panel data format and errors due to heteroscedasticity and autocorrelation may be involved in this regard. From the White test, the Chi-square statistic is 300.15 and the $p$-value is 0.002 . These results reject the null hypothesis of 
homoscedasticity. From the Wooldridge test, the F statistic is 4.83 and the $p$-value is 0.0284 . These results indicate the existence of serial correlation. The estimated value of the variance inflation factor (VIF) is 4.13. Since VIF is less than 10, conducting regression analysis is acceptable. Petersen [38] argues that such errors can be reduced using clustered standard errors estimated at the firm level. Therefore, this study calculates test statistics using clustered standard errors at the firm level. In consideration of the effect of timing difference, the values before the first stage $(\mathrm{t}-1)$ are used for independent variables. The CER activity index is recognized based on the announcement year. The industry dummy variable $\lambda_{j}$ and the year dummy variable $\eta_{t}$ are added to the model to control the effects of industrial characteristics and time-series trends. All variables, except for CER activity-related variables, are winsorized at the top and bottom $1 \%$, respectively, to eliminate the effects of outliers. The empirical model is as shown in Equation (3) below.

$$
\begin{aligned}
& \text { Inefficiency }_{i t+1}=\gamma_{0}+\gamma_{1}{ }^{*} \text { CER }_{i t}+\gamma_{2}{ }^{*} \text { Size }_{i t}+\gamma_{3}{ }^{*} \text { Leverage }_{i t}+\gamma_{4}{ }^{*} \text { MTB }_{i t}+\gamma_{5}{ }^{*} \text { EBIT }_{i t} \\
& +\gamma_{6}{ }^{*} \text { Dividend }_{i t}+\gamma_{7}{ }^{*} \text { Liquidity }_{i t}+\gamma_{8}{ }^{*} \text { Growth }_{i t}+\gamma_{9}{ }^{*} \text { Volaility }_{i t}+\lambda_{j}+\eta_{t}+\varepsilon_{i t}
\end{aligned}
$$

where, Inefficiency is one of the following depending on the model among Inefficiency1, Inefficiency2, Overinvest, Underinvest, Inefficiency $C A P E x$, InefficiencyR\&D, where, CER is one of the following depending on the model among CER, CER1, CER2, CER3, CER4, CER5.

\section{Empirical Results}

\subsection{Descriptive Statistics and Test of Difference in Means}

Table 1 shows the descriptive statistics of the variables used in the analysis. The average of Inefficiency1, the proxy for investment inefficiency, was 0.0207. It implies that investment inefficiency could be problematic in Korea. The average of Inefficiency 2 was 0.0004 . The variable Inefficiency 2 is obtained from residuals, whilst the other variable Inefficiency 1 is obtained from the absolute values of residuals. The average value of Inefficiency 2 is smaller than that of Inefficiency 1 and it means that Equation (1), which estimated investment inefficiency, was effective. The averages of Overinvest and Underinvest were 0.0105 and 0.0102 , respectively. The averages of Inefficiency $C_{C A P E X}$ and Inefficiency ${ }_{R \& D}$ were 0.0199 and 0.0070 , respectively. The average of CER was 0.3460 . Since the values of CER are standardized values based on a full score of 1 , this means that the CER activities of Korean companies are insufficient on average. However, the standard deviation of CERs was 0.2229 , indicating that differences among firms were rather large. Therefore, it is necessary to examine whether the differences contribute to positive or negative aspects of CERs. Among the detailed items of CER activities, environmental strategy (CER1), environmental organization (CER2), and environmental management (CER3) were shown to be actively implemented, while the environmental performance (CER4) and responses to stakeholders (CER5) were shown to be at insufficient levels.

Table 2 shows the result of tests of the differences in means and medians of CER between the overinvestment and underinvestment sub-samples. The classifications of sub-samples are based on the signs of residuals of the model by Richardson [37]. Observations with positive (negative) signs of residuals are classified as overinvestment (underinvestment) sub-samples. The average CERs for overinvestment and underinvestment sub-samples are 0.3660 and 0.3342 , respectively. These two values are significantly different at the $1 \%$ level. It means that companies that overinvest are active in CER activities on average. If CER activities are considered as an efficient investment alternative, no difference between the two samples will be observed. If investment inefficiency is premised, this means that the problem of CER activities used for incentives to form good reputations of managers is larger than the problem of CER activities used for incentives to hide the manager's disposition to avoid risks. In addition, it can be seen that CER activities are being exploited as a means of overinvestments in connection with the items, environmental strategy (CER1), environmental organization (CER2), and environmental management (CER3). These sub-items can be easily increased discretionally by managers in short periods of time. If managers expand CER activities by changing internal policies or 
making facility investments for their private benefits, instead of doing so based on cost-benefit analysis, the company's investment efficiency will decrease.

Table 1. Descriptive statistics.

\begin{tabular}{ccccccc}
\hline Variables & $\mathbf{N}$ & Mean & Median & STD & Max & Min \\
\hline Inefficiency1 & 2471 & 0.0207 & 0.0133 & 0.0241 & 0.1938 & 0.0000 \\
Inefficiency2 & 2471 & 0.0004 & -0.0054 & 0.0318 & 0.1938 & -0.1439 \\
Overinvest & 2471 & 0.0105 & 0.0000 & 0.0239 & 0.1938 & 0.0000 \\
Underinvest & 2471 & 0.0102 & 0.0054 & 0.0149 & 0.1439 & 0.0000 \\
Inefficiency CAPEX $_{\text {Inefficiency }}$ RED & 2471 & 0.0199 & 0.0132 & 0.0232 & 0.1812 & 0.0000 \\
CER & 2471 & 0.0070 & 0.0041 & 0.0089 & 0.0642 & 0.0000 \\
CER1 & 2471 & 0.3460 & 0.3767 & 0.2229 & 0.9333 & 0.0000 \\
CER2 & 2471 & 0.4206 & 0.4308 & 0.2675 & 1.0000 & 0.0000 \\
CER3 & 2471 & 0.4228 & 0.4571 & 0.2981 & 1.0000 & 0.0000 \\
CER4 & 2471 & 0.4126 & 0.4727 & 0.2768 & 1.0000 & 0.0000 \\
CER5 & 2471 & 0.1609 & 0.1538 & 0.1153 & 0.7615 & 0.0000 \\
Size & 2471 & 0.2320 & 0.1200 & 0.3115 & 1.0000 & 0.0000 \\
Leverage & 2471 & 19.8935 & 19.6417 & 1.5000 & 24.1218 & 17.0207 \\
MTB & 2471 & 1.1174 & 0.7365 & 1.2881 & 8.2331 & 0.0173 \\
EBIT & 2471 & 1.1703 & 0.8601 & 1.0643 & 6.4614 & 0.1930 \\
Dividend & 2471 & 0.0325 & 0.0305 & 0.0573 & 0.2126 & -0.1752 \\
Liquidity & 2471 & 0.0078 & 0.0046 & 0.0107 & 0.0662 & 0.0000 \\
Growth & 2471 & 0.4125 & 0.4141 & 0.1843 & 0.8449 & 0.0126 \\
Volatility & 2372 & 0.0999 & 0.0786 & 0.1749 & 1.2367 & -0.2398 \\
Industry CER & 2133 & 0.4955 & 0.4675 & 0.1626 & 1.0516 & 0.2221 \\
Manufacturing & 2471 & 0.3459 & 0.3831 & 0.1716 & 0.8410 & 0.0000 \\
Free cash flow & 2471 & 0.6495 & 1.0000 & 0.4772 & 1.0000 & 0.0000 \\
Managerial ability & 2471 & 0.0048 & 0.0085 & 0.0548 & 0.3926 & -0.4126 \\
Tobin's Q & 2467 & 0.8929 & 0.8178 & 0.5537 & 4.3319 & 0.0008 \\
Market-cap & 2471 & 1.1586 & 0.9671 & 0.6966 & 4.8054 & 0.4162 \\
Cash & 2471 & 26.0440 & 25.6914 & 1.7187 & 33.1267 & 22.1980 \\
Investment & 2471 & 0.0520 & 0.0332 & 0.0568 & 0.2858 & 0.0001 \\
& 0.0456 & 0.0290 & 0.0512 & 0.7013 & 0.0000 \\
\hline
\end{tabular}

Note: The definition of variables is presented in Table A2 of the Appendix A.

Table 2. Difference of corporate environmental responsibility (CER) index depending on investment inefficiency.

\begin{tabular}{ccccc}
\hline Groups/Variables & $\begin{array}{c}\text { Overinvestment } \\
\text { Firms }[\mathbf{N}=\mathbf{9 1 6}]\end{array}$ & $\begin{array}{c}\text { Underinvestment } \\
\text { Firms }[\mathbf{N}=\mathbf{1 5 5 5 ]}\end{array}$ & t-test & $\begin{array}{c}\text { Wilcoxon Rank } \\
\text { Sum Test }\end{array}$ \\
\hline \multirow{2}{*}{ CER } & 0.3660 & 0.3342 & $0.0006^{* * *}$ & $0.0020^{* * *}$ \\
& $(0.4013)$ & $(0.3553)$ & & \\
CER1 & 0.4505 & 0.4030 & $0.0000^{* * *}$ & $0.0000^{* * *}$ \\
& $(0.5231)$ & $(0.4154)$ & & \\
CER2 & 0.4505 & 0.4064 & $0.0004^{* * *}$ & $0.0005^{* * *}$ \\
CER3 & $(0.4571)$ & $(0.4571)$ & & $0.0043^{* * *}$ \\
& 0.4362 & 0.3987 & $0.0011^{* * *}$ & 0.9900 \\
CER4 & $(0.5000)$ & $(0.4364)$ & & \\
& 0.1636 & 0.1593 & 0.3683 & 0.2121 \\
\hline
\end{tabular}

Note: The definition of variables is presented in Table A2 of the Appendix A. Numbers in parentheses are median. $* * *$ and ${ }^{*}$ denote statistical significance at $1 \%$ and $10 \%$ confidence level, respectively. 


\subsection{Regression Results}

\subsubsection{Effects of CER Activities on Investment Inefficiency}

Table 3 shows the results of regression analysis of the effects of CER activities on investment inefficiency. The dependent variables of Models (1) and (2) are Inefficiency1 and Inefficiency2, respectively. In Models (1) and (2), both the coefficients of the CERs have significantly positive (+) values. This means that investment inefficiency increases as CER activity increases and supports Hypothesis 1. In particular, in Model (2), the positive coefficient of CER means that as the CER increases, the size of residual investment inefficiency increases, and the overinvestment increases. This means that in emerging market countries, unlike in developed countries, CER activities can be abused as a means for managers' private gains, leading to overinvestments. In the case of control variables, investment inefficiency increased significantly when the sizes of firms were smaller, the amounts of debts were smaller, and the market values were higher.

Table 3. The effect of CER activities on investment inefficiencies.

\begin{tabular}{|c|c|c|c|c|c|c|}
\hline Models & Model (1) & Model (2) & Model (3) & Model (4) & Model (5) & Model (6) \\
\hline Variables & Inefficiency $1_{t}$ & Inefficiency $2_{t}$ & Overinvest $_{t}$ & Underinvest $_{t}$ & Inefficiency CAPEX $t$ & Inefficiency $R E D t$ \\
\hline Intercept & $\begin{array}{c}0.0529 * * * \\
{[3.41]}\end{array}$ & $\begin{array}{l}0.0262 \\
{[1.48]}\end{array}$ & $\begin{array}{c}0.0396^{* * *} \\
{[2.80]}\end{array}$ & $\begin{array}{l}0.0134 \\
{[1.52]}\end{array}$ & $\begin{array}{c}0.0553 * * * \\
{[3.76]}\end{array}$ & $\begin{array}{c}0.0004 \\
{[0.06]}\end{array}$ \\
\hline$C E R_{t-1}$ & $\begin{array}{c}0.0121^{* *} \\
{[2.12]}\end{array}$ & $\begin{array}{c}0.0162^{* * *} \\
{[3.13]}\end{array}$ & $\begin{array}{c}0.0141 * * * \\
{[3.14]}\end{array}$ & $\begin{array}{c}-0.0020 \\
{[-0.67]}\end{array}$ & $\begin{array}{c}0.0107^{* *} \\
{[1.99]}\end{array}$ & $\begin{array}{c}0.0059^{* *} \\
{[2.17]}\end{array}$ \\
\hline Size $_{t-1}$ & $\begin{array}{c}-0.0013 \text { ** } \\
{[-2.13]}\end{array}$ & $\begin{array}{c}-0.0013 \\
{[-1.90]}\end{array}$ & $\begin{array}{c}-0.0013^{* *} \\
{[-2.29]}\end{array}$ & $\begin{array}{l}-0.0000 \\
{[-0.01]}\end{array}$ & $\begin{array}{c}-0.0014 * * \\
{[-2.30]}\end{array}$ & $\begin{array}{l}-0.0001 \\
{[-0.20]}\end{array}$ \\
\hline Leverage $_{t-1}$ & $\begin{array}{c}-0.0014 \text { **** } \\
{[-2.98]}\end{array}$ & $\begin{array}{l}-0.0006 \\
{[-1.15]}\end{array}$ & $\begin{array}{c}-0.0010 * * \\
{[-2.45]}\end{array}$ & $\begin{array}{l}-0.0004 \\
{[-1.54]}\end{array}$ & $\begin{array}{c}-0.0011 \text { ** } \\
{[-2.54]}\end{array}$ & $\begin{array}{c}-0.0008^{* * *} \\
{[-3.10]}\end{array}$ \\
\hline$M T B_{t-1}$ & $\begin{array}{c}0.0021^{* * *} \\
{[3.03]}\end{array}$ & $\begin{array}{l}0.0000 \\
{[0.01]}\end{array}$ & $\begin{array}{c}0.0010 \text { * } \\
{[1.78]}\end{array}$ & $\begin{array}{c}0.0010 * * \\
{[2.18]}\end{array}$ & $\begin{array}{c}0.0015^{* *} \\
{[2.48]}\end{array}$ & $\begin{array}{c}0.0015^{* * *} \\
{[3.10]}\end{array}$ \\
\hline$E B I T_{t-1}$ & $\begin{array}{l}0.0125 \\
{[0.69]}\end{array}$ & $\begin{array}{c}0.0628^{* * *} \\
{[3.77]}\end{array}$ & $\begin{array}{c}0.0376^{* * *} \\
{[2.62]}\end{array}$ & $\begin{array}{c}-0.0251 * * \\
{[-2.57]}\end{array}$ & $\begin{array}{l}0.0061 \\
{[0.37]}\end{array}$ & $\begin{array}{c}-0.0004 \\
{[-0.05]}\end{array}$ \\
\hline Dividend $_{t-1}$ & $\begin{array}{c}-0.1093 \\
{[-1.39]}\end{array}$ & $\begin{array}{c}-0.1870 \text { ** } \\
{[-2.17]}\end{array}$ & $\begin{array}{c}-0.1481 \text { * } \\
{[-2.17]}\end{array}$ & $\begin{array}{c}0.0388 \\
{[0.84]}\end{array}$ & $\begin{array}{c}-0.0578 \\
{[-0.78]}\end{array}$ & $\begin{array}{l}-0.0170 \\
{[-0.42]}\end{array}$ \\
\hline Liquidity $_{t-1}$ & $\begin{array}{l}0.0032 \\
{[0.66]}\end{array}$ & $\begin{array}{c}0.0044 \\
{[1.00]}\end{array}$ & $\begin{array}{l}0.0038 \\
{[0.93]}\end{array}$ & $\begin{array}{l}-0.0006 \\
{[-0.28]}\end{array}$ & $\begin{array}{l}0.0022 \\
{[0.47]}\end{array}$ & $\begin{array}{c}0.0056^{* * *} \\
{[2.68]}\end{array}$ \\
\hline Growth $_{t-1}$ & $\begin{array}{l}0.0036 \\
{[1.07]}\end{array}$ & $\begin{array}{l}-0.0041 \\
{[-0.93]}\end{array}$ & $\begin{array}{l}-0.0003 \\
{[-0.09]}\end{array}$ & $\begin{array}{l}0.0038 \\
{[1.57]}\end{array}$ & $\begin{array}{l}0.0016 \\
{[0.49]}\end{array}$ & $\begin{array}{l}-0.0009 \\
{[-0.69]}\end{array}$ \\
\hline Volatility $_{t-1}$ & $\begin{array}{c}-0.0008 \\
{[-0.15]}\end{array}$ & $\begin{array}{c}-0.0014 \\
{[-0.29]}\end{array}$ & $\begin{array}{c}-0.0011 \\
{[-0.26]}\end{array}$ & $\begin{array}{l}0.0003 \\
{[0.12]}\end{array}$ & $\begin{array}{c}-0.0000 \\
{[-0.00]}\end{array}$ & $\begin{array}{l}0.0008 \\
{[0.40]}\end{array}$ \\
\hline $\begin{array}{c}\text { Industry and } \\
\text { Year effect }\end{array}$ & Yes & Yes & Yes & Yes & Yes & Yes \\
\hline$N$ & 2125 & 2125 & 2125 & 2125 & 2125 & 2125 \\
\hline $\operatorname{Adj} \cdot R^{2}$ & 0.0341 & 0.0055 & 0.0181 & 0.0107 & 0.0383 & 0.1020 \\
\hline
\end{tabular}

Models (3) and (4) divided investment inefficiency into overinvestment and underinvestment to examine the effects of CER activities. In Model (3) where Overinvest is the dependent variable, the coefficient of CER has a positive value. On the other hand, in Model (4) where Underinvest is the dependent variable, the coefficient of CER is not significant. This suggests that CER may be a means of overinvestment in Korea, as in Model (2). This supports previous studies that argue for the negative effect of CER activities. In contrast, Model (4) suggests that CER is unlikely to be based on managers' incentive to avoid risks in Korea. Since interest in and demand for CER activities have increased only recently in Korea, managers with a disposition to avoid risks may have not responded initiatively because they might have not been proactively active in CER activities. 
Models (5) and (6) divide the path through which investment inefficiency occurs into capital expenditures and R\&D expenses to analyze the effects of CER activities. Models (5) and (6) use the investment inefficiency of capital expenditures (Inefficienc $y_{C A P E X}$ ), and the investment inefficiency of R\&D expenses (Inefficiency $y_{R D}$ ) as dependent variables, respectively. The coefficients of CER had significant positive $(+)$ values in both models. This shows that companies with many CER activities generally make inefficient investments.

The significance of most control variables is model dependent. The coefficients of Size are significantly negative in Models (1), (2), (3), and (5). Large companies are likely to have frequent information supply, e.g., analyst and media coverage, thereby investment inefficiency of large companies could diminish. The coefficients of Leverage are significantly negative in Models (1), (3), (5), and (6). These results imply that monitoring by debtholders could enhance investment efficiency. The coefficients of MTB are significantly positive in Models (1), (3), (4), (5), and (6). Because the high MTB ratio is related to a high degree of information asymmetry, the positive relations between MTB and investment inefficiency are straightforward. Alternatively, because the high MTB ratio is inversely related to future growth potential, again the positive relations could be explained. The coefficients of EBIT are significantly positive in Models (2) and (3), while the coefficients of EBIT are significantly negative in Model (4). Profitable companies are likely to overinvest under the presence of agency problems and the positive relations in Models (2) and (3) hold. Overall, an interesting feature is that the significance of the aforementioned control variables in Model (4) where the dependent variable is Underinvest. The coefficients of Size and Leverage are insignificant, whilst the coefficients are significant in Model (3). Our interpretation of these results is as follows. Outside monitoring could be effective at least in preventing overinvestments in that too much investment expense could be easily observed and directly affect the wealth of outside investors. On the contrary, outside monitoring may not be effective in cases of underinvestment in that observing and judging managers' behavior as underinvestment could be difficult.

\subsubsection{Effects of Individual Sub-items of CER Indices on Investment Inefficiency}

The CER indices by KCGS consist of five categories: Environmental strategy, environmental organization, environmental management, environmental performance, and responses to stakeholders. Table 4 shows the analysis of the effects of individual sub-items of CER indices on investment inefficiency. Through the foregoing, concrete paths through which certain factors of CER activities are misused for overinvestments can be identified. The dependent variable is Inefficiency1, which was used in the Model (1) in Table 3. The independent variables used are the individual sub-items of CER (CER1-CER5).

In Models (1), (2), and (3), the coefficients of environmental strategy (CER1), environmental organization (CER2), and environmental management (CER3) are positive $(+)$ and significant. This means that these items are the major factors that increase investment inefficiency during CER activities. These sub-items can be easily increased through short-term decision-making of managers. These items facilitate signaling to the capital market because they contain information on policies for CER activities, facility investments, etc. Therefore, these items can be an effective means for managers to build their good reputation in short periods of time. On the other hand, in Models (4) and (5), the coefficients of environmental performance (CER4) and responses to stakeholders (CER5) were not significant. In the case of these two items, the outcomes of environmental investments (e.g., energy and waste savings, greenhouse gas emissions), and actual performance, such as joining international initiatives, should be proved. Therefore, these two items are less likely to be misused in the pursuit of managers' private benefits. Emphasizing such activities further is judged to induce positive effects of CER activities. 
Table 4. The effect of sub-items of CER on investment inefficiencies.

\begin{tabular}{|c|c|c|c|c|c|}
\hline Models & Model (1) & Model (2) & Model (3) & Model (4) & Model (5) \\
\hline \multirow{2}{*}{ Variables } & \multicolumn{5}{|c|}{ Inefficiency $1_{t}$} \\
\hline & $C E R=C E R 1$ & $C E R=C E R 2$ & $C E R=C E R 3$ & $C E R=C E R 4$ & $C E R=C E R 5$ \\
\hline \multirow{2}{*}{ Intercept } & $0.0471^{* * *}$ & $0.0518^{* * *}$ & $0.0478^{* * *}$ & $0.0361^{* *}$ & $0.0457^{* * *}$ \\
\hline & [3.19] & {$[3.71]$} & [3.21] & {$[2.51]$} & {$[3.01]$} \\
\hline \multirow{2}{*}{$C E R_{t-1}$} & $0.0072^{* *}$ & $0.0116^{* * *}$ & 0.0083 * & 0.0026 & 0.0043 \\
\hline & {$[2.11]$} & [3.25] & [1.80] & {$[0.38]$} & [1.36] \\
\hline \multirow{2}{*}{$\operatorname{Size}_{t-1}$} & $-0.0011^{*}$ & $-0.0013^{* *}$ & $-0.0011^{*}$ & -0.0005 & -0.0010 * \\
\hline & {$[-1.83]$} & {$[-2.43]$} & {$[-1.85]$} & {$[-0.95]$} & {$[-1.65]$} \\
\hline \multirow{2}{*}{ Leverage $_{t-1}$} & $-0.0014^{* * *}$ & $-0.0014^{* * *}$ & $-0.0014^{* * *}$ & $-0.0013^{* * *}$ & $-0.0013^{* * *}$ \\
\hline & [-2.95] & {$[-2.98]$} & {$[-3.01]$} & {$[-2.86]$} & {$[-2.86]$} \\
\hline \multirow{2}{*}{$\mathrm{MTB}_{t-1}$} & $0.0021^{* * *}$ & $0.0020 * * *$ & $0.0021^{* * *}$ & $0.0022^{* * *}$ & $0.0021^{* * *}$ \\
\hline & [3.13] & [2.93] & [3.05] & [3.14] & [3.10] \\
\hline \multirow{2}{*}{$E B I T_{t-1}$} & 0.0115 & 0.0123 & 0.0121 & 0.0121 & 0.0131 \\
\hline & {$[0.63]$} & {$[0.68]$} & {$[0.67]$} & {$[0.67]$} & [0.73] \\
\hline \multirow{2}{*}{ Dividend $_{t-1}$} & -0.1033 & -0.1100 & -0.1075 & -0.1065 & -0.1115 \\
\hline & {$[-1.31]$} & {$[-1.41]$} & {$[-1.37]$} & {$[-1.35]$} & {$[-1.42]$} \\
\hline \multirow{2}{*}{ Liquidity $_{t-1}$} & 0.0029 & 0.0026 & 0.0031 & 0.0031 & 0.0035 \\
\hline & {$[0.61]$} & {$[0.56]$} & {$[0.66]$} & [0.65] & [0.71] \\
\hline \multirow{2}{*}{ Growth $_{t-1}$} & 0.0032 & 0.0031 & 0.0036 & 0.0035 & 0.0040 \\
\hline & {$[0.98]$} & {$[0.93]$} & [1.09] & [1.09] & [1.23] \\
\hline \multirow{2}{*}{ Volatility $_{t-1}$} & -0.0008 & -0.0007 & -0.0006 & -0.0007 & -0.0008 \\
\hline & {$[-0.15]$} & {$[-0.14]$} & {$[-0.12]$} & {$[-0.14]$} & {$[-0.16]$} \\
\hline $\begin{array}{c}\text { Industry and } \\
\text { Year effect }\end{array}$ & Yes & Yes & Yes & Yes & Yes \\
\hline$N$ & 2125 & 2125 & 2125 & 2125 & 2125 \\
\hline $\operatorname{Adj} \cdot R^{2}$ & 0.0333 & 0.0372 & 0.0330 & 0.0299 & 0.0313 \\
\hline
\end{tabular}

Note: The definition of variables is presented in Table A2 of the Appendix A. Numbers in the brackets are z-statistics adjusted by the firm-level clustered standard error. ${ }^{* * *}, * *$, and ${ }^{*}$ denote statistical significance at $1 \%, 5 \%$, and $10 \%$ confidence level, respectively.

\subsubsection{Robustness Check}

\section{Two-Stage Least Square}

The abovementioned analysis sets the time difference to prescribe the causal relationship between CER activities and investment inefficiency. The findings of the abovementioned analysis show that CER activities increase investment inefficiency. However, if the reverse causality exists so that inefficient firms actively exploit CER activities due to agency problems, the possibility of endogeneity problems cannot be completely eliminated. Therefore, to control the possible endogeneity problem, regression analyses are carried out using the two-stage least square method, and the results are presented in Table 5. Model (1) is the result of the first stage estimation. The coefficients of the instrument variables Industry CER and Manufacturing, respectively, are positive and significant. Both variables satisfy the criterion for judgment of adequacy based on the rule of thumb since their $t$ values are at least 3.3. The dependent variables of Models (2), (3), and (4), which are the results of the second stage estimation, are Inefficiency1, Overinvest, and Underinvest, respectively. Identically to the results shown in Tables 3 and 4, the coefficients of CER have significant positive values in both Models (2) and (3). The coefficient of CER is not significant in Model (4), where the dependent variable is Underinvest. Therefore, it can be inferred that CER activities significantly increase investment inefficiency and that this is associated with overinvestment problems. Therefore, the findings of this paper are robustly supported even after controlling endogeneity problems. Durbin statistics and Wu-Hausman statistics were estimated to evaluate the adequacy of the instrumental variables and according to the results, the statistics were not significant in all models. This means that the null hypothesis that the residual of the first-stage model 
does not affect the investment inefficiency cannot be rejected and that the instrument variable has the effect to adequately mitigate endogeneity.

In the second stage regressions, the coefficient of Dividend in Models (2) and (3) are significantly negative. Considering the free cash flow problems, these positive relations can be easily explained. The coefficient of Growth in Model (4) is significantly positive, while the coefficients are insignificant in other models. Companies in the early stage of growth could show a high growth rate, while they are likely to have insufficient funds. For this reason, underinvestment could occur. The results of other control variables are overall similar to the previous results.

Table 5. The effect of CER activities on investment inefficiencies using IV (Instrumental Variable) and two-stage least square (2SLS).

\begin{tabular}{|c|c|c|c|c|}
\hline Models & Model (1) & Model (2) & Model (3) & Model (4) \\
\hline \multirow{2}{*}{ Variables } & 1st Stage & \multicolumn{3}{|c|}{ 2nd Stage } \\
\hline & $C E R_{\mathrm{t}-1}$ & Inefficiency $1_{\mathrm{t}}$ & Overinvest $_{\mathrm{t}}$ & Underinvest $_{\mathrm{t}}$ \\
\hline Intercept & $\begin{array}{c}-1.2070 * * * \\
{[-26.88]}\end{array}$ & $\begin{array}{c}0.0512^{* * *} \\
{[4.20]}\end{array}$ & $\begin{array}{c}0.0365^{* * *} \\
{[3.03]}\end{array}$ & $\begin{array}{c}0.0147 * \\
{[1.89]}\end{array}$ \\
\hline Predicted CER ${ }_{t-1}$ & & $\begin{array}{c}0.0130^{* *} \\
{[2.07]}\end{array}$ & $\begin{array}{c}0.0136^{* *} \\
{[2.20]}\end{array}$ & $\begin{array}{c}-0.0006 \\
{[-0.16]}\end{array}$ \\
\hline Size $_{t-1}$ & $\begin{array}{c}0.0600^{* * *} \\
{[29.61]}\end{array}$ & $\begin{array}{c}-0.0017^{* * *} \\
{[-2.84]}\end{array}$ & $\begin{array}{c}-0.0015^{* *} \\
{[-2.47]}\end{array}$ & $\begin{array}{l}-0.0002 \\
{[-0.64]}\end{array}$ \\
\hline Leverage $_{t-1}$ & $\begin{array}{c}0.0005 \\
{[0.23]}\end{array}$ & $\begin{array}{c}-0.0016^{* * *} \\
{[-3.55]}\end{array}$ & $\begin{array}{c}-0.0011 * * \\
{[-2.50]}\end{array}$ & $\begin{array}{c}-0.0005^{*} \\
{[-1.69]}\end{array}$ \\
\hline MTB $_{t-1}$ & $\begin{array}{c}0.0114^{* * * *} \\
{[4.22]}\end{array}$ & $\begin{array}{c}0.0023^{* * *} \\
{[4.22]}\end{array}$ & $\begin{array}{c}0.0012 * * \\
{[2.23]}\end{array}$ & $\begin{array}{c}0.0011^{* * *} \\
{[3.18]}\end{array}$ \\
\hline$E B I T_{t-1}$ & $\begin{array}{l}0.0265 \\
{[0.48]}\end{array}$ & $\begin{array}{c}0.0174 \\
{[1.56]}\end{array}$ & $\begin{array}{c}0.0395 * * * \\
{[3.59]}\end{array}$ & $\begin{array}{c}-0.0220 * * * \\
{[-3.11]}\end{array}$ \\
\hline Dividend $_{t-1}$ & $\begin{array}{c}-0.5480 * \\
{[-1.80]}\end{array}$ & $\begin{array}{c}-0.1365^{* *} \\
{[-2.24]}\end{array}$ & $\begin{array}{c}-0.1557^{* * *} \\
{[-2.59]}\end{array}$ & $\begin{array}{l}0.0192 \\
{[0.50]}\end{array}$ \\
\hline Liquidity $_{t-1}$ & $\begin{array}{c}0.0194 \\
{[1.29]}\end{array}$ & $\begin{array}{l}0.0035 \\
{[1.14]}\end{array}$ & $\begin{array}{l}0.0035 \\
{[1.15]}\end{array}$ & $\begin{array}{c}0.0000 \\
{[0.01]}\end{array}$ \\
\hline Growth $_{t-1}$ & $\begin{array}{l}-0.0107 \\
{[-0.71]}\end{array}$ & $\begin{array}{l}0.0043 \\
{[1.41]}\end{array}$ & $\begin{array}{l}-0.0001 \\
{[-0.03]}\end{array}$ & $\begin{array}{c}0.0044^{* *} \\
{[2.26]}\end{array}$ \\
\hline Volatility $_{t-1}$ & $\begin{array}{c}0.0044 \\
{[0.25]}\end{array}$ & $\begin{array}{l}-0.0009 \\
{[-0.26]}\end{array}$ & $\begin{array}{c}-0.0010 \\
{[-0.29]}\end{array}$ & $\begin{array}{c}0.0001 \\
{[0.04]}\end{array}$ \\
\hline $\begin{array}{l}\text { Industry CER }{ }_{t-1} \\
\text { Manufacturing }_{t-1}\end{array}$ & $\begin{array}{c}0.6456^{* * *} \\
{[24.51]} \\
0.0557^{* * *} \\
{[9.27]}\end{array}$ & & & \\
\hline Industry and Year effect & Yes & Yes & Yes & Yes \\
\hline$N$ & 2125 & 2125 & 2125 & 2125 \\
\hline $\operatorname{Adj} \cdot R^{2}$ & 0.7291 & 0.0238 & 0.0183 & 0.0076 \\
\hline Durbin statistics & - & 0.8190 & 0.8339 & 0.9725 \\
\hline Wu-Hausman statistics & - & 0.8196 & 0.8344 & 0.9726 \\
\hline
\end{tabular}

Note: The definition of variables is presented in Table A2 of the Appendix A. Numbers in the brackets are z-statistics adjusted by the firm-level clustered standard error. ${ }^{* * *}, * *$, and $*$ denote statistical significance at $1 \%, 5 \%$, and $10 \%$ confidence level, respectively.

Effects of CER Activities on Investment Inefficiency by the Degree of Agency Problems

This paper interpreted the foregoing results based on agency problems. However, investment inefficiency may not be due to agency problems. It may appear simply because temporary abnormal investment spending on CER activities was expanded. To show that the foregoing results are based on agency problems, the entire samples are divided according to variables that reflect the possibility of occurrence of agency problems to conduct additional analyses. If the interpretation in this study 
based on agency problems is valid, more significant results will be obtained from subsamples with higher possibilities of occurrence of agency problems. The ratio of free cash flow to the total asset (Free cash flow) and the ratio of sales to the total asset (Managerial ability) are proxies of the degree of agency problems.

Panel A in Table 6 shows the results of the analysis of subsamples depending on the sign of free cash flows. Models (1)-(3) are subsamples with high possibilities of occurrence of agency problems because free cash flows in the models exceed 0. Models (4)-(6) are subsamples in which free cash flows are below zero. Investment inefficiency, which is a dependent variable, is estimated with Inefficiency 1 (Models (1) and (4)), Overinvest (Models (2) and (5)), and Underinvest (Models (3) and (6)) as before. In Models (1) and (2), the coefficients of CER are significant positive values, respectively. On the other hand, the coefficients of CER in Models (4) and (5) are not significant. This means that the relationship between CER activities and overinvestment problems mainly comes from samples where the possibility of occurrence of agency problems is high. Panel B shows the results of the analysis of subsamples divided using the median of the ratios of sales to the total assets. Models (1)-(3) are subsamples in which the ratios of sales to total asset exceed the median and the managerial ability is excellent. Models (4)-(6) are samples in which the ratios of sales to total asset do not exceed the median and the managerial ability is inferior. The coefficients of CER have a positive value only in Model (5). This means that CER activities are misused as overinvestments in firms with poor managerial ability high agency costs. The coefficient of CER in Model (4) is not significant. This result might have happened because incompetent managers were not active in CERs, which are a relatively recent matter of interest in emerging market countries. The results in Table 6 are summarized as follows. CER activities increase investment inefficiency and especially overinvestments are increased due to agency problems. Significant coefficients of CER are mainly observed in subsamples in which the possibility of occurrence of agency problems is high. This clarifies that the investment inefficiency resulting from CER activities is not due to temporary abnormal investment expenditures.

In Panel A, within positive free cash flows subsamples in Models (1)-(3), the results of control variables are overall consistent with previous results. The coefficients of Size, Leverage, and Dividend are negative and significant in Models (1) and (2), while the coefficient is insignificant in Model (3), underinvestment subsamples. The coefficients of EBIT are significantly positive in Models (1) and (2). Even though the coefficient of EBIT is negative in Model (3), the coefficient is insignificant. The coefficient of MTB is significantly positive only in Model (3). Within negative free cash flows subsamples in Models (4)-(6), the coefficients of Size and Dividend are all insignificant. Because free cash flows are dried out, dividend payout is likely at best to maintain the previous level and the insignificant relations are easily understandable. In addition, information supply would be limited for underperforming companies. Analyst coverage is known to be biased upward and so is media coverage. The coefficients of Leverage are negative and marginally significant in Models (4) and (5). These results imply that monitoring by debtholders is consistently effective. The coefficients of MTB are significantly positive in Models (4) and (5). The coefficient of EBIT is negative only in Model (6). In Panel B, within superior managerial ability subsamples in Models (1)-(3), the coefficients of Size and Leverage are significantly negative in Models (1) and (2), while the coefficient is insignificant in Model (3), underinvestment subsamples. The coefficients of Dividend are consistently insignificant, whilst the coefficients of Liquidity became significantly negative in Models (1) and (2). The coefficients of MTB and EBIT are consistently insignificant. Within inferior managerial ability subsamples in Models (4)-(6), the coefficients of control variables are overall insignificant. The coefficient of Leverage is significantly negative only in Model (6). The coefficients of MTB are significantly positive in Models (4)-(6). The coefficients of Dividend and Liquidity are negative and marginally significant only in Model (5). The coefficients of Growth are significant but inconsistent in Models (5) and (6). 
Table 6. The effect of CER on investment inefficiencies depending on the degree of agency problems.

\begin{tabular}{|c|c|c|c|c|c|c|}
\hline \multicolumn{7}{|c|}{ Panel A: Samples are Partitioned by the Sign of Free Cash Flows. } \\
\hline \multirow{2}{*}{ Models } & Model (1) & Model (2) & Model (3) & Model (4) & Model (5) & Model (6) \\
\hline & \multicolumn{3}{|c|}{ Free Cash Flow $>0$} & \multicolumn{3}{|c|}{ Free Cash Flow $\leq 0$} \\
\hline Variables & Inefficiency $1_{t}$ & Overinvest $_{t}$ & Underinvest $_{t}$ & Inefficiency $1_{t}$ & Overinvest $t$ & Underinvest $_{t}$ \\
\hline Intercept & $\begin{array}{c}0.0651^{* * *} \\
{[3.61]}\end{array}$ & $\begin{array}{c}0.0538^{* * *} \\
{[3.01]}\end{array}$ & $\begin{array}{l}0.0113 \\
{[0.93]}\end{array}$ & $\begin{array}{l}0.0254 \\
{[1.03]}\end{array}$ & $\begin{array}{l}0.0104 \\
{[0.49]}\end{array}$ & $\begin{array}{l}0.0151 \\
{[1.22]}\end{array}$ \\
\hline$C E R_{t-1}$ & $\begin{array}{c}0.0132 * * \\
{[2.03]}\end{array}$ & $\begin{array}{c}0.0155^{* * *} \\
{[2.84]}\end{array}$ & $\begin{array}{c}-0.0024 \\
{[-0.56]}\end{array}$ & $\begin{array}{l}0.0092 \\
{[1.10]}\end{array}$ & $\begin{array}{l}0.0118 \\
{[1.47]}\end{array}$ & $\begin{array}{c}-0.0026 \\
{[-0.66]}\end{array}$ \\
\hline$S i z e_{t-1}$ & $\begin{array}{c}-0.0018^{* *} \\
{[-2.36]}\end{array}$ & $\begin{array}{c}-0.0018^{* *} \\
{[-2.49]}\end{array}$ & $\begin{array}{c}-0.0000 \\
{[-0.11]}\end{array}$ & $\begin{array}{c}-0.0002 \\
{[-0.27]}\end{array}$ & $\begin{array}{c}-0.0003 \\
{[-0.31]}\end{array}$ & $\begin{array}{l}0.0000 \\
{[0.06]}\end{array}$ \\
\hline Leverage $_{t-1}$ & $-0.0019^{* * *}$ & $\begin{array}{c}-0.0012 \\
{[-1.92]}\end{array}$ & $\begin{array}{c}-0.0007 \\
{[-1.54]}\end{array}$ & $\begin{array}{c}-0.0010 * \\
{[-1.70]}\end{array}$ & $\begin{array}{c}-0.0010^{*} \\
{[-1.85]}\end{array}$ & $\begin{array}{l}0.0000 \\
{[0.06]}\end{array}$ \\
\hline$M T B_{t-1}$ & $\begin{array}{c}0.0013 \\
{[1.41]}\end{array}$ & $\begin{array}{c}0.0000 \\
{[0.00]}\end{array}$ & $\begin{array}{c}0.0013 \\
{[1.96]}\end{array}$ & $\begin{array}{c}0.0020 * \\
{[1.88]}\end{array}$ & $\begin{array}{c}0.0017^{*} \\
{[1.67]}\end{array}$ & $\begin{array}{l}0.0003 \\
{[0.44]}\end{array}$ \\
\hline$E B I T_{t-1}$ & $\begin{array}{c}0.0496^{* *} \\
{[2.08]}\end{array}$ & $\begin{array}{c}0.0658^{* * *} \\
{[2.67]}\end{array}$ & $\begin{array}{l}-0.0162 \\
{[-1.06]}\end{array}$ & $\begin{array}{c}-0.0448 \\
{[-1.56]}\end{array}$ & $\begin{array}{c}-0.0058 \\
{[-0.24]}\end{array}$ & $\begin{array}{c}-0.0390 * * * \\
{[-2.68]}\end{array}$ \\
\hline Dividend $_{t-1}$ & $\begin{array}{c}-0.23611^{* * *} \\
{[-2.79]}\end{array}$ & $\begin{array}{c}-0.2509^{* * *} \\
{[-3.09]}\end{array}$ & $\begin{array}{c}0.0148 \\
{[0.31]}\end{array}$ & $\begin{array}{l}0.1069 \\
{[0.70]}\end{array}$ & $\begin{array}{l}0.0619 \\
{[0.48]}\end{array}$ & $\begin{array}{c}0.0449 \\
{[0.48]}\end{array}$ \\
\hline Liquidity $_{t-1}$ & $\begin{array}{l}-0.0012 \\
{[-0.22]}\end{array}$ & $\begin{array}{c}-0.0023 \\
{[-0.50]}\end{array}$ & $\begin{array}{l}0.0011 \\
{[0.37]}\end{array}$ & $\begin{array}{l}0.0078 \\
{[1.00]}\end{array}$ & $\begin{array}{l}0.0113 \\
{[1.62]}\end{array}$ & $\begin{array}{c}-0.0036 \\
{[-1.04]}\end{array}$ \\
\hline Growth $_{t-1}$ & $\begin{array}{l}0.0022 \\
{[0.65]}\end{array}$ & $\begin{array}{l}0.0018 \\
{[0.45]}\end{array}$ & $\begin{array}{c}0.0004 \\
{[0.16]}\end{array}$ & $\begin{array}{l}0.0040 \\
{[0.83]}\end{array}$ & $\begin{array}{c}-0.0029 \\
{[-0.90]}\end{array}$ & $\begin{array}{l}0.0068 \\
{[1.48]}\end{array}$ \\
\hline Volatility $_{t-1}$ & $\begin{array}{c}-0.0064 \\
{[-1.01]}\end{array}$ & $\begin{array}{c}-0.0071 \\
{[-1.29]}\end{array}$ & $\begin{array}{l}0.0007 \\
{[0.19]}\end{array}$ & $\begin{array}{l}0.0070 \\
{[1.01]}\end{array}$ & $\begin{array}{l}0.0071 \\
{[1.14]}\end{array}$ & $\begin{array}{l}-0.0001 \\
{[-0.03]}\end{array}$ \\
\hline Industry and Year effect & Yes & Yes & Yes & Yes & Yes & Yes \\
\hline$N$ & 1333 & 1333 & 1333 & 792 & 792 & 792 \\
\hline $\operatorname{Adj} . R^{2}$ & 0.0381 & 0.0206 & 0.0001 & 0.0408 & 0.0151 & 0.0220 \\
\hline \multicolumn{7}{|c|}{ Panel B: Samples are Partitioned by the Median Value of Managerial Ability. } \\
\hline \multirow{2}{*}{ Models } & Model (1) & Model (2) & Model (3) & Model (4) & Model (5) & Model (6) \\
\hline & \multicolumn{3}{|c|}{ Managerial Ability > Median } & \multicolumn{3}{|c|}{ Managerial Ability $\leq$ Median } \\
\hline Variables & Inefficiency $1_{t}$ & Overinvest $t$ & Underinvest $_{t}$ & Inefficiency $1_{t}$ & Overinvest $t_{t}$ & Underinvest $t_{t}$ \\
\hline Intercept & $\begin{array}{c}0.0982 * * * \\
{[4.42]}\end{array}$ & $\begin{array}{c}0.0771 * * * \\
{[4.02]}\end{array}$ & $\begin{array}{c}0.0211 * \\
{[1.96]}\end{array}$ & $\begin{array}{l}0.0127 \\
{[0.69]}\end{array}$ & $\begin{array}{l}0.0082 \\
{[0.46]}\end{array}$ & $\begin{array}{l}0.0045 \\
{[0.36]}\end{array}$ \\
\hline$C E R_{t-1}$ & $\begin{array}{c}0.0084 \\
{[1.05]}\end{array}$ & $\begin{array}{l}0.0111 \\
{[1.55]}\end{array}$ & $\begin{array}{c}-0.0027 \\
{[-0.73]}\end{array}$ & $\begin{array}{l}0.0114 \\
{[1.46]}\end{array}$ & $\begin{array}{c}0.0138^{* *} \\
{[2.36]}\end{array}$ & $\begin{array}{c}-0.0023 \\
{[-0.50]}\end{array}$ \\
\hline Size $_{t-1}$ & $\begin{array}{c}-0.0023^{* *} \\
{[-2.34]}\end{array}$ & $\begin{array}{c}-0.0022 \text { ** } \\
{[-2.50]}\end{array}$ & $\begin{array}{c}-0.0001 \\
{[-0.15]}\end{array}$ & $\begin{array}{c}-0.0001 \\
{[-0.19]}\end{array}$ & $\begin{array}{c}-0.0004 \\
{[-0.51]}\end{array}$ & $\begin{array}{c}0.0002 \\
{[0.46]}\end{array}$ \\
\hline Leverage $_{t-1}$ & $\begin{array}{c}-0.0018 * * * \\
{[-2.89]}\end{array}$ & $\begin{array}{c}-0.0017^{* * *} \\
{[-3.67]}\end{array}$ & $\begin{array}{l}-0.0001 \\
{[-0.17]}\end{array}$ & $\begin{array}{l}-0.0011 \\
{[-1.38]}\end{array}$ & $\begin{array}{l}-0.0002 \\
{[-0.31]}\end{array}$ & $\begin{array}{c}-0.0008^{* *} \\
{[-2.17]}\end{array}$ \\
\hline $\mathrm{MTB}_{t-1}$ & $\begin{array}{l}0.0009 \\
{[0.93]}\end{array}$ & $\begin{array}{l}0.0001 \\
{[0.13]}\end{array}$ & $\begin{array}{l}0.0008 \\
{[1.23]}\end{array}$ & $\begin{array}{c}0.0035^{* * *} \\
{[3.78]}\end{array}$ & $\begin{array}{c}0.0023^{* * *} \\
{[2.71]}\end{array}$ & $\begin{array}{c}0.0011 \text { * } \\
{[1.75]}\end{array}$ \\
\hline$E B I T_{t-1}$ & $\begin{array}{l}0.0134 \\
{[0.86]}\end{array}$ & $\begin{array}{l}0.0248 \\
{[1.58]}\end{array}$ & $\begin{array}{c}-0.0114 \\
{[-1.21]}\end{array}$ & $\begin{array}{c}-0.0080 \\
{[-0.33]}\end{array}$ & $\begin{array}{c}0.0104 \\
{[0.52]}\end{array}$ & $\begin{array}{c}-0.0185 \\
{[-1.48]}\end{array}$ \\
\hline Dividend $_{t-1}$ & $\begin{array}{c}-0.0961 \\
{[-0.94]}\end{array}$ & $\begin{array}{c}-0.1234 \\
{[-1.27]}\end{array}$ & $\begin{array}{l}0.0273 \\
{[0.46]}\end{array}$ & $\begin{array}{c}-0.1194 \\
{[-1.14]}\end{array}$ & $\begin{array}{c}-0.1438 * \\
{[-1.83]}\end{array}$ & $\begin{array}{c}0.0244 \\
{[0.34]}\end{array}$ \\
\hline Liquidity $_{t-1}$ & $\begin{array}{c}-0.0189 * * * \\
{[-2.74]}\end{array}$ & $\begin{array}{c}-0.0154 * * \\
{[-2.34]}\end{array}$ & $\begin{array}{c}-0.0036 \\
{[-1.00]}\end{array}$ & $\begin{array}{l}0.0126 \\
{[1.64]}\end{array}$ & $\begin{array}{c}0.0105^{*} \\
{[1.76]}\end{array}$ & $\begin{array}{l}0.0021 \\
{[0.58]}\end{array}$ \\
\hline Growth $_{t-1}$ & $\begin{array}{l}0.0037 \\
{[0.48]}\end{array}$ & $\begin{array}{l}0.0103 \\
{[1.24]}\end{array}$ & $\begin{array}{c}-0.0065^{* *} \\
{[-2.09]}\end{array}$ & $\begin{array}{l}0.0028 \\
{[0.93]}\end{array}$ & $\begin{array}{c}-0.0047^{* *} \\
{[-2.13]}\end{array}$ & $\begin{array}{c}0.0075^{* *} \\
{[2.47]}\end{array}$ \\
\hline Volatility $_{t-1}$ & $\begin{array}{c}-0.0090 \\
{[-1.06]}\end{array}$ & $\begin{array}{c}-0.0110 * \\
{[-1.73]}\end{array}$ & $\begin{array}{l}0.0021 \\
{[0.56]} \\
\end{array}$ & $\begin{array}{l}0.0063 \\
{[1.07]} \\
\end{array}$ & $\begin{array}{l}0.0072 \\
{[1.35]}\end{array}$ & $\begin{array}{c}-0.0009 \\
{[-0.23]}\end{array}$ \\
\hline Industry and Year effect & Yes & Yes & Yes & Yes & Yes & Yes \\
\hline$N$ & 1057 & 1057 & 1057 & 1068 & 1068 & 1068 \\
\hline $\operatorname{Adj} . R^{2}$ & 0.0280 & 0.0197 & -0.0039 & 0.0613 & 0.0300 & 0.0229 \\
\hline
\end{tabular}

Note: The definition of variables is presented in Table A2 of the Appendix A. Numbers in the brackets are z-statistics adjusted by the firm-level clustered standard error. ${ }^{* * *}, * *$, and $*$ denote statistical significance at $1 \%, 5 \%$, and $10 \%$ confidence level, respectively. 
Effects of CER Activities on Firm Value

Table 7 shows the results of the analysis of how CER activities affect the corporate value estimated with Tobin's $Q$. Through the foregoing, this study showed that CERs were abused for managers' private benefits, especially causing overinvestment problems. However, even if managers' CER activities are internally perceived as inefficient investments, whether it is accurately evaluated in the external capital market is a separate issue. For instance, if the evaluation in the external capital market is accurate, the relationship between CER activities and firm value should be negative in subsamples where overinvestments were made. On the other hand, if the managers' intention of increasing CER activities is not accurately understood in the external capital market, the coefficient of CER should have a positive value. This study can complement previous studies in that whereas previous studies mainly examined the relationship between CER activities and firm value, excluding managers' incentives. In contrast, this study analyzed the effects of CER activities centering on managers' incentives. Table 7 shows the results of verification of whether the managers' incentives to conduct CER activities are accurately evaluated in the capital market and the evaluation is reflected on the corporate value. Models (1), (2), and (3) are the entire samples, overinvestment subsamples, and underinvestment subsamples, respectively. The identification of overinvestment and underinvestment is based on the model by Richardson [37].

Table 7. The effect of CER activities on firm value depending on the types of investment inefficiencies.

\begin{tabular}{|c|c|c|c|}
\hline Models & Model (1) & Model (2) & Model (3) \\
\hline \multirow{2}{*}{ Variables } & Total Sample & Overinvestment Firms & Underinvestment Firms \\
\hline & \multicolumn{3}{|c|}{ Tobin's $Q_{t}$} \\
\hline \multirow{2}{*}{ Intercept } & $0.8542^{* * *}$ & 0.0921 & $1.3804^{* * *}$ \\
\hline & [2.72] & [0.19] & [3.39] \\
\hline \multirow{2}{*}{$C E R_{t-1}$} & -0.0072 & $-0.2637^{* *}$ & 0.1576 \\
\hline & {$[-0.08]$} & {$[-2.07]$} & {$[1.28]$} \\
\hline \multirow{2}{*}{ Market-cap $_{t-1}$} & -0.0145 & 0.0128 & $-0.0338^{* *}$ \\
\hline & {$[-1.21]$} & {$[0.69]$} & {$[-2.14]$} \\
\hline \multirow{2}{*}{ Leverage $_{t-1}$} & $-0.0631 * * *$ & -0.0378 & $-0.0744^{* * *}$ \\
\hline & {$[-4.62]$} & {$[-1.41]$} & {$[-4.90]$} \\
\hline \multirow{2}{*}{$M_{t-1}$} & $0.5288^{* * *}$ & $0.5251^{* * *}$ & $0.5406^{* * *}$ \\
\hline & [16.02] & [10.37] & [13.69] \\
\hline \multirow{2}{*}{$E B I T_{t-1}$} & -0.1439 & -0.1597 & -0.2104 \\
\hline & {$[-0.47]$} & {$[-0.37]$} & {$[-0.55]$} \\
\hline \multirow{2}{*}{ Cash $_{t-1}$} & 0.1156 & 0.0371 & 0.1635 \\
\hline & {$[0.44]$} & {$[0.10]$} & {$[0.50]$} \\
\hline \multirow{2}{*}{ Growth $_{t-1}$} & -0.0857 & -0.0222 & -0.1053 \\
\hline & {$[-1.21]$} & {$[-0.16]$} & {$[-1.30]$} \\
\hline \multirow{2}{*}{ Investment $_{t-1}$} & 0.0328 & 0.2961 & -0.5216 \\
\hline & {$[0.14]$} & {$[0.75]$} & {$[-1.27]$} \\
\hline \multirow{2}{*}{ Volatility $_{t-1}$} & 0.0034 & 0.0112 & 0.0051 \\
\hline & {$[0.05]$} & [0.09] & {$[0.06]$} \\
\hline Industry and Year effect & Yes & Yes & Yes \\
\hline$N$ & 2125 & 785 & 1340 \\
\hline $\operatorname{Adj} . R^{2}$ & 0.631 & 0.649 & 0.623 \\
\hline
\end{tabular}

Note: The definition of variables is presented in Table A2 of the Appendix A. Numbers in the brackets are z-statistics adjusted by the firm-level clustered standard error. ${ }^{* *}$ and ${ }^{* *}$ denote statistical significance at $1 \%$ and $5 \%$ confidence level, respectively.

In Model (1), the coefficient of CER was not significant. This means that CER activities are perceived as inefficient investment behavior with no significant effect on the increase in firm value in the Korean capital market. In Model (2), the overinvestment subsample, the coefficient of CER had a 
significant negative value. This means that overinvestment behavior that exploits CER activities will destroy firm value leading to the reduction of shareholders' wealth. This also means that managers' use of CER for their private benefits is negatively evaluated in the capital market, too. This shows that the interpretation in this study based on the agency theory is appropriate. In Model (3), the underinvestment subsample, the coefficient of $C E R$ was not significant. The results in Table 7 again suggest that, unlike developed countries, CER activities are highly likely to be misused as a negative means that would undermine corporate value in emerging market countries such as Korea.

The coefficients of MTB are significantly positive in all models. The coefficients of Leverage are significantly negative in Models (1) and (3). The coefficient of market capitalization is negative only in Model (3).

\section{Conclusions}

We tested the hypothesis based on extensive data on CER by KCGS; considering which CER activities may either increase investment inefficiency due to agency problems or improve investment efficiency and provide a viable investment alternative in Korea, as a typical emerging country.

We found the following results. First, active CER activities lead to investment inefficiency, especially based on managers' incentives for overinvestments. Our results suggest that CER activities can be regarded as agency costs and thus can be perceived as inefficient investments in Korea. In contrast, CER activities can be an efficient investment alternative in the U.S. with a mature capital market and a high level of investor protection. Similar results are observed in China where government control over enterprises is strong. Second, the positive relationship between CER activities and investment inefficiency is prominent in the subsamples with large, free cash flows or low managerial ability. This implies that the first result is a phenomenon based on managers' incentive to pursue private benefits, and is not due to temporary increases in abnormal investment spending on CER activities. Agency problems are more serious in emerging countries than in developed countries. Owner-managers of firms in emerging countries often control overall management owing to their majority ownership under a concentrated structure. This indicates that environmental differences, e.g., internal corporate governance and maturity of the capital market, could cause differences in CER activities between countries. Third, active CER reduced corporate value in the overinvestment subsample. This result suggests that managers' internal evaluation of CER as overinvestments could lead to consistent evaluations in external capital markets.

This study provides additional empirical evidence that the functions of CER activities in emerging countries could be negative, while CER activities have positive functions in developed countries. This suggests that in emerging countries, it is necessary to proactively introduce internal management control devices to complement vulnerable capital markets before implementing CER activities. This raises a concern for economic actors. Even though interest in CER activities is expanding rapidly, policymakers should prepare an economic environment that provides informational accessibility to market participants and enables assessment of CER investments. Stakeholders including shareholders and creditors should prepare a proactive internal management control device, e.g. a committee under the board of directors that assesses the implementation of ESG activities. Further, this study shows that managers' internal evaluation of CER activities could lead to consistent evaluations in external capital markets, thereby complementing previous literature. Nevertheless, the result raises another concern that different results could occur depending on environmental differences like the maturity of the capital market.

This study has two limitations due to the accessibility of data. First, only listed firms are analyzed. Second, our sample covers relatively short periods, and the data by KCGS is not public in full. Considering that the agency problem could be more severe in private companies than in public companies, a further study that covers both private and public companies could highlight the role of capital market maturity. In addition, when extended samples become available, generalized results across countries could be derived. 
Author Contributions: S.K.K. performed the literature review, designed the empirical model, and wrote the article. H.S.B. performed the conceptualization, developed the research hypotheses, analyzed the data, and supervised the whole process. All authors read and approved the final manuscript.

Funding: This research was supported by Hallym University Research Fund, 2018 (HRF-201808-004).

Acknowledgments: We would like to thank the editors and reviewers for their insightful comments on this study.

Conflicts of Interest: The authors declare no conflict of interest.

\section{Appendix A}

Table A1. Composition of CER index by Korea Corporate Governance Service.

\begin{tabular}{|c|c|c|}
\hline Item & Points (\%) & Contents \\
\hline $\begin{array}{l}\text { Environmental } \\
\text { strategies }\end{array}$ & $45(15.0)$ & $\begin{array}{l}\text { - Environmental strategies and policies to implement CER activities } \\
\text { - The establishment of related investment plans }\end{array}$ \\
\hline $\begin{array}{l}\text { Environmental } \\
\text { organizations }\end{array}$ & $30(10.0)$ & $\begin{array}{l}\text { - Review of environmental management activities in the board of directors } \\
\text { - Existence of an organization dedicated to planning and execution of CER } \\
\text { - Periodic education about the environment }\end{array}$ \\
\hline $\begin{array}{c}\text { Environmental } \\
\text { management }\end{array}$ & 115 (38.4) & $\begin{array}{l}\text { - The establishment of an evaluation system for environmental performance. } \\
\text { - Management of chemicals and greenhouse gas emissions- Review of and } \\
\text { support for suppliers' environmental management, } \\
\text { - Adoption of green procurement policies and supporting systems } \\
\text { - Facility investments related to CER activities }\end{array}$ \\
\hline $\begin{array}{l}\text { Environmental } \\
\text { performance }\end{array}$ & 85 (28.3) & $\begin{array}{l}\text { - Quantitative assessment based on emissions of greenhouse gas, reductions } \\
\text { in waste and chemicals, and water and energy savings. }\end{array}$ \\
\hline $\begin{array}{l}\text { Responses to } \\
\text { stakeholders }\end{array}$ & $25(8.3)$ & $\begin{array}{l}\text { - The existence of communication channels with stakeholders } \\
\text { - Disclosure of environmental information and verification of the } \\
\text { information by independent institutions } \\
\text { - Support for and cooperation with the community for environmental } \\
\text { preservation activities. } \\
\text { - Participation in domestic initiatives }\end{array}$ \\
\hline Total & 300 (100) & - \\
\hline
\end{tabular}

Table A2. Definition of variables.

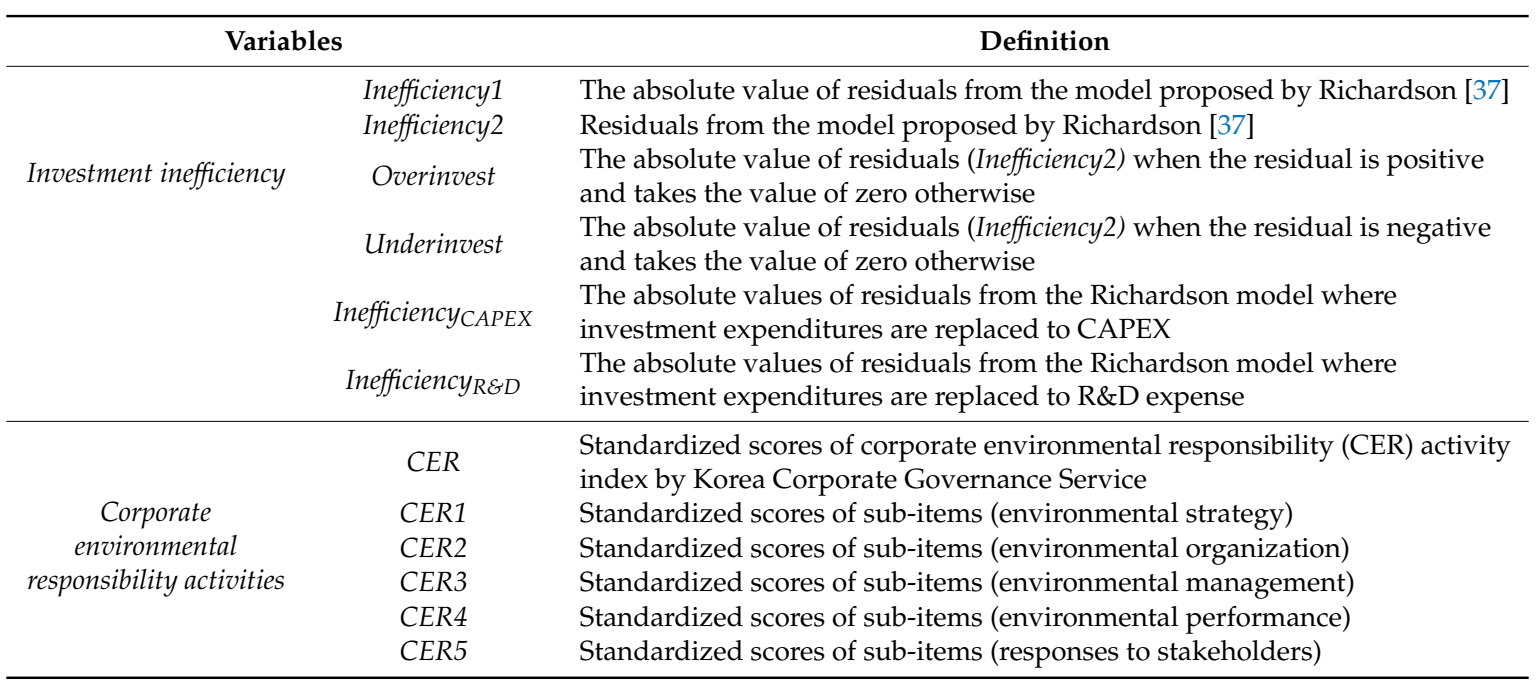


Table A2. Cont.

\begin{tabular}{|c|c|c|}
\hline \multicolumn{2}{|c|}{ Variables } & Definition \\
\hline \multirow{11}{*}{ Other variables } & Leverage & The ratio of the total debt to equity capital \\
\hline & EBIT & The ratio of operating profits to total asset \\
\hline & Dividend & The ratio of the amounts of dividends to total asset \\
\hline & Liquidity & The ratio of liquid assets to total asset \\
\hline & Volatility & The standard deviation of monthly stock return over the past five years \\
\hline & Industry CER & $\begin{array}{l}\text { The average of the CER activity index by industry based on the three digits of } \\
\text { the Korea Standard Industry code }\end{array}$ \\
\hline & Manufacturing & $\begin{array}{l}\text { Dummy variables that take the value of one to firms in the manufacturing } \\
\text { industry and take zero otherwise }\end{array}$ \\
\hline & Free cash flow & $\begin{array}{l}\text { Operating profits minus interest costs, dividends, and corporate taxes, } \\
\text { divided by the total asset }\end{array}$ \\
\hline & Market-cap & The natural logarithm of market capitalization \\
\hline & Cash & The ratio of cash and cash equivalent to total asset \\
\hline & Investment & The sum of CAPEX and R\&D expense to total asset \\
\hline
\end{tabular}

\section{References}

1. Klassen, R.; McLaughlin, C. The Impact of Environmental Management on Firm Performance. Manag. Sci. 1996, 42, 1199-1214. [CrossRef]

2. Welch, E.; Ashish, R.; Yasuhumi, M. The Promises and Pitfalls of ISO 14001 for Competitiveness and Sustainability. Greener Manag. Int. 2003, 44, 59-73. [CrossRef]

3. Cai, L.; Cui, J.; Jo, H. Corporate Environmental Responsibility and Firm Risk. J. Bus. Ethics 2016, 139, 563-594. [CrossRef]

4. Barnea, A.; Rubin, A. Corporate Social Responsibility as a Conflict between Shareholders. J. Bus. Ethics 2010, 97, 71-86. [CrossRef]

5. Oh, W.; Chang, Y.; Martynov, A. The Effect of Ownership Structure on Corporate Social Responsibility: Empirical Evidence from Korea. J. Bus. Ethics 2011, 104, 283-297. [CrossRef]

6. Jensen, M.; Meckling, W. Theory of the Firm: Managerial Behavior, Agency Costs and Ownership Structure. J. Financ. Econ. 1976, 3, 305-360. [CrossRef]

7. Fama, E.; Jensen, M. Separation of Ownership and Control. J. Law Econ. 1983, 26, 301-325. [CrossRef]

8. Nehrt, C. Timing and Intensity Effects of Environmental Investments. Strateg. Manag. J. 1996, 17, 535-547. [CrossRef]

9. Miles, M.; Covin, J. Environmental Marketing: A Source of Reputational, Competitive, and Financial Advantage. J. Bus. Ethics 2000, 23, 299-311. [CrossRef]

10. Fisman, R.; Heal, G.; Nair, V. Corporate Social Responsibility: Doing Well by Doing Good? Unpublished. Unpublished.

11. Blacconiere, W.; Patten, D. Environmental Disclosures, Regulatory Costs, and Changes in Firm Value. J. Account. Econ. 1994, 18, 357-377. [CrossRef]

12. Dowell, G.; Hart, S.; Yeung, B. Do Corporate Global Environmental Standards Create or Destroy Market Value? Manag. Sci. 2000, 46, 1059-1074. [CrossRef]

13. El Ghoul, S.; Guedhami, O.; Kim, H.; Park, K. Corporate Environmental Responsibility and the Cost of Capital: International Evidence. J. Bus. Ethics 2018, 149, 335-361. [CrossRef]

14. Cheng, B.; Ioannou, I.; Serafeim, G. Corporate Social Responsibility and Access to Finance. Strateg. Manag. J. 2014, 35, 1-23. [CrossRef]

15. Zeng, S.; Qin, Y.; Zeng, G. Impact of Corporate Environmental Responsibility on Investment Efficiency: The Moderating Roles of the Institutional Environment and Consumer Environmental Awareness. Sustainability 2019, 11, 1-21. [CrossRef]

16. Shleifer, A.; Vishny, R. A Survey of Corporate Governance. J. Financ. 1997, 52, 737-783. [CrossRef] 
17. Johnson, S.; La Porta, R.; Lopez-de-Silanes, F.; Shleifer, A. Tunneling. Am. Econ. Rev. 2000, 90, $22-27$. [CrossRef]

18. Benlemlih, M.; Bitar, M. Corporate Social Responsibility and Investment Efficiency. J. Bus. Ethics 2018, 148, 647-671. [CrossRef]

19. Rahamn, N.; Post, C. Measurement Issues in Environmental Corporate Social Responsibility (ECSR): Toward a Transparent, Reliable, and Construct Valid Instrument. J. Bus. Ethics 2012, 105, 307-319. [CrossRef]

20. Friedman, M. The Social Responsibility of Business Is to Increase Profit. Unpublished. Unpublished.

21. Brammer, S.; Brooks, C.; Pavelin, S. Corporate Social Performance and Stock Returns: UK Evidence from Disaggregate Measures. Financ. Manag. 2006, 35, 97-116. [CrossRef]

22. Mahapatra, S. Investor Reaction to a Corporate Social Accounting. J. Bus. Finan. Account. 1984, 11, $29-40$. [CrossRef]

23. Aupperle, K.; Carroll, A.; Hatfield, J. An Empirical Examination of the Relationship between Corporate Social Responsibility and Profitability. Acad. Manag. J. 1985, 28, 446-463.

24. Gangi, F.; Varrone, N. Screening Activities by Socially Responsible Funds: A Matter of Agency? J. Clean. Prod. 2018, 197, 842-855. [CrossRef]

25. Lee, J.; Byun, H.; Park, K. Product Market Competition and Corporate Social Responsibility Activities: Perspectives from an Emerging Economy. Pac.-Basin Financ. J. 2018, 49, 60-80. [CrossRef]

26. Kliestik, T.; Kovacova, M.; Podhorska, I.; Kliestikova, J. Searching for Key Sources of Goodwill Creation as New Global Managerial Challenge. Pol. J. Manag. Stud. 2018, 17, 144-154. [CrossRef]

27. Kliestik, T.; Misankova, M.; Valaskova, K.; Svabova, L. Bankruptcy Prevention: New Effort to Reflect on Legal and Social Changes. Sci. Eng. Ethics 2018, 24, 791-803. [CrossRef] [PubMed]

28. Jensen, M. Agency Costs of Free Cash Flow, Corporate Finance, and Takeovers. Am. Econ. Rev. 1986, 76, 323-329.

29. Stulz, R. Managerial Discretion and Optimal Financing Policies. J. Financ. Econ. 1990, 26, 3-27. [CrossRef]

30. Stulz, R. Managerial Control of Voting Rights: Financing Policies and Market for Corporate Control. J. Financ. Econ. 1988, 20, 25-54. [CrossRef]

31. Burkart, M.; Panunzi, F.; Shleifer, A. Family Firms. J. Financ. 2003, 58, 2167-2201. [CrossRef]

32. Wright, P.; Ferris, S. Agency Conflict and Corporate Strategy: The Effect of Divestment on Corporate Value. Strateg. Manag. J. 1997, 18, 77-83. [CrossRef]

33. Delmas, M.; Pekovic, S. Environmental Standards and Labor Productivity: Understanding the Mechanisms that Sustain Sustainability. J. Organ. Behav. 2013, 34, 230-252. [CrossRef]

34. Cui, J.; Jo, H.; Na, H. Does Corporate Social Responsibility Affect Information Asymmetry? J. Bus. Ethics 2018, 148, 549-572. [CrossRef]

35. Gangi, F.; Meles, A.; Monferrà, S.; Mustilli, M. Does Corporate Social Responsibility Help the Survivorship of SMEs and Large Firms? Glob. Financ. J. 2020, 43, 100402. [CrossRef]

36. Godfrey, P.; Merrill, C.; Hansen, J. The Relationship between Corporate Social Responsibility and Shareholder Value: An Empirical Test of the Risk Management Hypothesis. Strateg. Manag. J. 2009, 30, 425-445. [CrossRef]

37. Richardson, S. Overinvestment of Free Cash Flow. Rev. Account. Stud. 2006, 11, 159-189. [CrossRef]

38. Petersen, M. Estimating Standard Errors in Finance Panel Data Sets: Comparing Approaches. Rev. Financ. Stud. 2009, 22, 435-480. [CrossRef]

(C) 2020 by the authors. Licensee MDPI, Basel, Switzerland. This article is an open access article distributed under the terms and conditions of the Creative Commons Attribution (CC BY) license (http://creativecommons.org/licenses/by/4.0/). 